\title{
THE ABOLITION OF LIVE ANIMAL EXPORT
}

\author{
RACHAEL SHAW
}

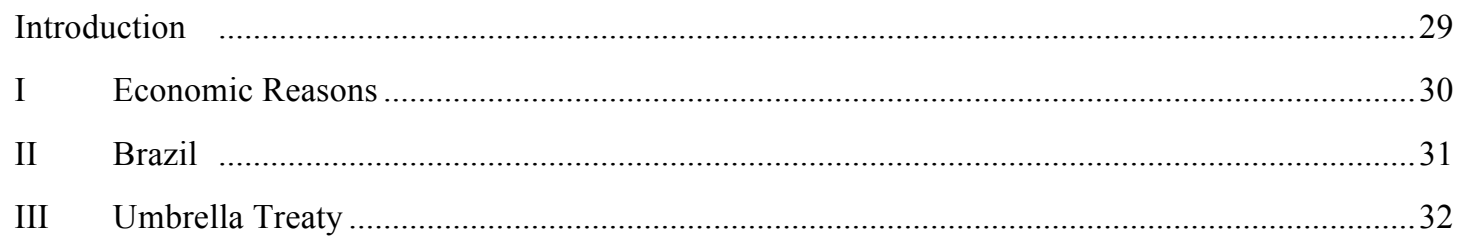

\section{INTRODUCTION}

The fundamental premise of the primary article is that Australia must end the commercial export of live farm animals. I wholeheartedly agree. I am in favour of abolishing live animal export because I do not see any way that live animal export can ever be humane.

It is incontrovertible that there have been countless deaths of animals during these arduous journeys. But the number of deaths during transit should not be determinative of whether a transit has been humane or whether an exporter has complied with animal welfare standards. The reality is that an animal may survive the journey but suffer agonizing stress throughout. Animals may go without water for up to 24 hours and experience sudden changes in heat and humidity. ${ }^{1}$ For ships that depart Australia, there is one veterinarian for every 500 animals. Needless to say, 'certain stressors imposed on animals during the journey can never be alleviated through increased regulation'. ${ }^{2}$ In addition, studies show that international buyers of livestock often transport

BA, LLB (University of New England), GDLP (Law Society of South Australia); Animal and Criminal Lawyer, Co-Chair of the Law Society of South Australia's Animal Law Committee.

1 R T Norris and G J Norman, Meat and Livestock Australia, National Livestock Exports Mortality Summary 2004 (2005), <http://www.livecorp.com.au/LC/files/c2/c2fa879c-ed7249d4-8579-f231dbd87e0a.pdf> 27.

2 L Morfuni, 'Pain for Profit: An Analysis of the Live Export Trade' (2011) 16 Deakin Law Review 497, 499 
the animals following purchase in car boots or on roof racks in extreme temperatures. $^{3}$

Despite my belief that equal protection should be afforded to all animals, I am acutely aware that such a belief is not shared by the majority of Australians. For that reason, the argument against live export for economic reasons, as set out by Seamus Brand in the primary article, is an argument that is likely to engender support. The author rightly points out that Australia has failed to regulate the live export industry successfully. This comment will focus in Part I on the economic arguments that support a ban, in Part II on the approach to animal welfare taken in Brazil, and in Part III on the merits of an umbrella treaty, before concluding that Australia should follow the lead taken by New Zealand and end the export trade in live animals.

\section{ECONOMIC REASONS}

The primary article sets out the economic reasons why live export will ultimately fail. The facts underpinning the economic basis for the abolition of live export are powerful. Various studies have concluded that the live export industry is unsustainable in the long term. ${ }^{4}$ Research points to the economic benefits of domestic processing. For example, a sheep processed domestically is worth 20 per cent more to the Australian economy than one exported live. ${ }^{5}$

In addition, the Australian Meat Industry Employees Union ('AMIEU') has opposed the live export trade for many years not only due to the cruelty associated with live export but also because of its contribution to the closing of numerous slaughterhouses across Australia (and the consequent loss of

3 K J Craig, 'Beefing up the Standard: The Ramification of Australia's Regulation of Live Export and Suggestions for Reform' (2013) 11 Macquarie Law Journal 51, 55 citing Ban Live Export, About Live Export (2012) <http://www.banliveexport.com/>.

4 See, for example, ACIL Tasman, 'An economic analysis of the live exportation of cattle from northern Australia' October 2012; C Wall, 'Submission to the Senate Standing Committees on Rural Affairs and Transport Inquiry into Animal Welfare standards in Australia's live export Markets' 15 July 2011; ACIL Tasman, 'The value of live sheep exports from Western Australia' March 2009.

5 ACIL Tasman, Australian live sheep exports: Economic analysis of Australian live sheep and sheep meat trade, $2009<\mathrm{http}: / /$ www.banliveexport.com/documents/ACIL-Tasman2009-Australian-Live-Sheep-Exports.pdf>. 
jobs for its members). ${ }^{6}$ It is appropriate that the author has referred to the economic basis of decisions regarding live export both in Australia and internationally throughout the article.

\section{BRAZIL}

The author rightly highlights the 'strides' taken by Brazil to regulate its live export industry. The enshrining of an obligation to protect animals from cruelty in its Constitution is a significant foundation for preventing animal cruelty. Brazil's Constitution has meant that cock fighting and the Oxen Festival (which involves attacking an ox as it runs through a village) have been banned. $^{7}$

Brand highlights the high animal welfare standards in respect of live export that must be met because of the fact that the European Union ('EU') is one of Brazil's live export destinations. This is truly a unique arrangement whereby the EU requires all of its exporters of live animals, including Brazil, to be subjected to audits. Despite the World Trade Organisation's rules and obligations which are designed to prevent and eliminate trade barriers, the EU has suspended imports from countries that do not maintain certain standards. ${ }^{8}$

As noted by the primary article, the EU is not Brazil's largest importer of live animals. However, it is reasonable to assume that the standards of animal welfare achieved by reason of the EU audits is translating into better animal welfare standards for all live animals exported from Brazil. In other words, it would be unlikely that animal welfare was at acceptable standards only for EU exports and not for others.

See, for example, M Journeaux, AMIEU, Media Release: 'Meatworkers' Union Condemns Live Export Trade as "Unfixable" Following Vietnam Horrors", 20 May 2015. $<$ https://amieuqld.asn.au/vietnam-live-export-horror/>.

7 See Lane Azevedo Clayton, 'Overview of Brazil's Legal Structure for Animal Issues' (2011) Animal Legal \& Historical Center, Michigan State University College of Law $<$ https://www.animallaw.info/article/overview-brazils-legal-structure-animal-issues>, discussing the Oxen Festival Case (Appeal to the Federal Supreme Court, Recurso Extraordinario n.153.531/SC. RT 753/101).

8 For example, the EU suspended the import of horse meat from Mexico following an audit which revealed, among other things, that horses travelling from the United States to Mexico to be slaughtered were suffering during transport: Human Society of the United States, Press Release: 'European Union Suspends Mexican Horsemeat Imports, 8 December 2014, $<\mathrm{http} / / / \mathrm{www}$. humanesociety.org/news/press_releases/2014/12/eu-suspends-mexicanhorsemeat-imports-120814.html>. 
The emphasis that Brazil places on animal welfare expressly through its Constitution, regulation and pronouncements is obviously admirable and something that Australia should seek to emulate. However, assessing the prevalence or otherwise of animal cruelty is inherently difficult - regardless of the jurisdiction. Most instances of animal cruelty against livestock:

take place on private property, in remote locations far removed from the public eye. In many cases, investigating authorities have to rely on whistleblowers or 'tip-offs' from third parties that have unlawfully trespassed on factory farms and witnessed animal suffering. ${ }^{9}$

Brand notes that the primary importers of Brazil's livestock are Lebanon and Venezuela. Australia's major importer of livestock is Indonesia. The difference in the wealth of these nations is obvious. Indonesia has an enormous population to feed and is not considered a wealthy country. Although Indonesia has animal cruelty laws, they are rarely enforced. The combination of a lack of enforcement with a lack of wealth translates to poor animal welfare standards in Indonesia. In my view, this makes the comparison between the live export experience of Australia and Brazil difficult.

\section{UMBRELLA TREATY}

Brand notes that there is no international instrument that governs animal welfare. I agree that this is surprising given the existence of an international instrument for the international trade of animals for food (both live and processed), the use of animals for scientific purposes, the transportation of pets worldwide and the regular disputes that arise in relation to fishing and marine life in international waters. I also agree that the adoption of Favre's International Convention for the Protection of Animals ('ICPA') would be a symbolic step towards creating consensus worldwide about the way we should treat animals. Such a step would be symbolic because there is limited enforceability of such instruments. However, international conventions are often the key to the introduction of laws or the reform of existing laws.

The adopting of the ICPA or a treaty created as a consequence of the ICPA has the potential to economically benefit those countries who participate. It may be that the adoption of the ICPA or corresponding treaty would make a country more attractive for trade or tourism. As Brand points out in the primary article, Australia could gather significant credit at home and abroad

9 D Cao, Animal Law in Australia and New Zealand, (LawBook Co, 2010), 216. 
if it were to sign up to a treaty dealing with live animal export. However, in my view, the efforts to create a treaty dealing with live export would be better spent reducing the live export trade and transitioning from live export to processed meat export. This was the view of a Senate Select Committee as long ago as $1985 .{ }^{10}$ In addition, Australia has actively supported Indonesia's intention to become self-sufficient. ${ }^{11}$ In the primary article's conclusion, it is plain that Brand recognises that the Australian livestock market must adapt to the changing environment. In my view, in order to abolish live export, the appropriate country to emulate is New Zealand.

10 Senate Select Committee on Animal Welfare, Parliament of Australia, Export of Live Sheep from Australia, (1985) 185, 186.

11 Jessica Blanchett and Bruno Zeller, 'No Winners in the Suspension of the Livestock Trade with Indonesia' (2012) 14 University of Notre Dame Australia Law Review 56. 